\title{
Analisis Reaksi Pasar Atas Pengumuman Peringkat Kinerja Perusahaan Dalam Pengelolaan Lingkungan Hidup
}

\author{
Komang Winda Trinadewi ${ }^{1}$ \\ Fakultas Ekonomi dan Bisnis \\ Universitas Udayana, Indonesia. \\ Email: windatrinadewi@gmail.com
}

\author{
Gerianta Wirawan Yasa ${ }^{2}$ \\ Fakultas Ekonomi dan Bisnis \\ Universitas Udayana, Indonesia.
}

\begin{abstract}
ABSTRAK
Penelitian ini bertujuan untuk mengetahui adanya reaksi pasar pada peristiwa pengumuman PROPER dan apakah terdapat perbedaan reaksi pasar antara peringkat baik dan peringkat buruk PROPER. Penelitian ini merupakan event study dengan jendela peristiwa selama 5 hari. Penelitian dilakukan pada perusahaan peserta PROPER yang terdaftar di Bursa Efek Indonesia periode 2015 sampai dengan 2017. Jumlah sampel yang memenuhi kriteria adalah sebanyak 39 perusahaan. Pengumuman PROPER diukur dengan menggunakan abnormal return. Teknik analisis yang digunakan adalah uji one sample t-test dan uji independent $t$-test. Hasil pengujian menunjukan bahwa pengumuman PROPER direaksi negatif oleh pasar modal, dan tidak terdapat perbedaan reaksi pasar antara peringkat baik dan peringkat buruk.
\end{abstract}

Kata Kunci : Event Study; Abnormal Return; Kinerja Lingkungan; PROPER.

\section{Analysis of Market Reaction to the Announcement of the Company's Performance Rating in Environmental Management}

\section{ABSTRACT}

This study aims to determine the market reaction to the PROPER announcement event and whether there are differences in market reactions between good ratings and poor PROPER ratings. This research is an event study with a window of events for 5 days. The study was conducted on PROPER participating companies listed on the Indonesia Stock Exchange from 2015 to 2017. The number of samples that met the criteria were 39 companies. PROPER announcements are measured using abnormal returns. The analysis technique used is the one sample ttest and the independent $t$-test. The test results show that the PROPER announcement was reacted negatively by the capital market, and there was no difference in market reaction between good ratings and bad ratings.

Keywords: Event Study; Abnormal Return; Environmental Performance; PROPER

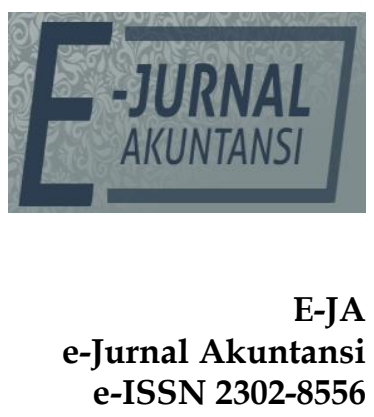

Vol. 29 No. 3

Denpasar, Desember 2019

Hal. 1152-1165

Artikel masuk: 27 Agustus 2019

Tanggal diterima:

01 Oktober 2019 


\section{PENDAHULUAN}

Perkembangan industri-industri baru di Indonesia berkembang dengan pesat. Perkembangan ini menyebabkan beberapa manajemen yang tidak peduli dengan lingkungan akan melakukan upaya tersebut tanpa memperhitungkan dampak negatif yang dapat mempengaruhi lingkungan disekitar perusahaannya hanya demi meningkatkan kemakmuran pemegang saham. Berkembangnya industriindustri tidak hanya berdampak negatif bagi masyarakat, namun juga terdapat dampak positif yang ditimbulkannya. Dampak positif terhadap pertumbuhan sektor industri yaitu terbukanya lapangan pekerjaan sehingga dapat mengurangi pengangguran di Indonesia dan dapat meningkatkan perekonomian negara. Namun dampak negatif yang dapat terjadi adalah ketika beberapa pabrik tidak memperhatikan kelestarian lingkungan dengan membuang hasil limbah cair ke sungai tanpa proses pengolahan limbah maka hal tersebut akan menimbulkan pencemaran, hal ini juga berdampak pada penurunan kualitas air. Air yang tercemar limbah sangat berbahaya bagi kehidupan manusia dan ekosistem di sekitar lingkungan tersebut. Hal tersebut merupakan sumber utama lain kerusakan lingkungan, maka selain memikirkan keuntungan ekonomis, sudah seharusnya perusahaan juga lebih bertanggung jawab terhadap lingkungan (Shrivastava, 1995).

Berdasarkan data dari kompas, sekitar 70 persen kerusakan lingkungan di Indonesia disebabkan oleh operasional industri pertambangan. Wilayah hutan, daratan, hingga lautan Indonesia menjadi kawasan eksploitasi industri-industri yang kepentingannya bertentangan dengan peraturan di Indonesia. PT. Freeport Indonesia merupakan salah satu perusahaan yang memberikan dampak negatif terhadap lingkungan. Freeport telah membuang limbah pasir kimiawi (tailing) ke Sungai Ajkwa dimana limbah tailing tersebut telah mencemari perairan di muara sungai Ajkwa dan mengkontaminasi mahkluk hidup di sungai tersebut sehingga mengakibatkan punahnya sejumlah spesies aquatik. Selain itu, hutan seluas 23.000 ha mati dan air sungai meluap karena pendangkalan yang diakibatkan oleh pengendapan tailing tersebut (Nasution, 2018).

PT. Lapindo Brantas Inc merupakan contoh kasus lain perusahaan yang memberikan dampak negatif terhadap lingkungan. Semburan lumpur lapindo yang pertama kali muncul pada tahun 2006 di Sidoarjo, Jawa Timur tersebut disebabkan karena dalam kegiatan pengeboran, PT. Lapindo Brantas Inc kurang tepat dalam membuat prognosis pengeboran, sehingga menyebabkan terjadinya semburan lumpur di wilayah tersebut. Semburan lumpur memberikan dampak buruk bagi masyarakat dan perekonomian di wilayah tersebut. Semburan lumpur tersebut mengandung logam berat dan senyawa organik berbahaya yang bersifat karsinogen. Kandungan logam berat dan hidrokarbon yang sangat tinggi tersebut telah membahayakan kesehatan manusia yang tinggal disekitar tanggul lumpur lapindo. Selain itu, semburan lumpur lapindo membawa dampak bagi lingkungan, persawahan, dan ternak warga (VOA Indonesia, 2018).

John Elkington (1997) dalam Alhaddi (2015) menyatakan apabila perusahaan menginginkan perusahaannya dapat beroperasi dalam jangka panjang maka perusahaan wajib memperhatikan aspek 3P yaitu profit, people, dan planet. Konsep ini menunjukkan bahwa tanggung jawab organisasi tidak hanya pada maksimalisasi laba yang diperoleh organisasi dan pemegang saham, tetapi juga 
menuntut tanggung jawab organisasi terhadap masyarakat dan lingkungan. Dengan adanya konsep 3P ini, keseimbangan antara profit-people-planet pada perusahaan menjadi sangat penting dan menjadi pertimbangan masyarakat dalam memilih perusahaan.

Menurut Sri Tjahjono (2013) terdapat tiga alasan mengapa perusahaan wajib mendukung dan menerapkan corporate social responsibility sejalan dengan kegiatan usahanya. Pertama, perusahaan merupakan bagian dari masyarakat dan oleh sebab itu wajar apabila perusahaan memperhatikan kepentingan masyarakat. Kedua, masyarakat dan perusahaan sebaiknya memiliki hubungan yang saling menguntungkan. Ketiga, kegiatan tanggung jawab sosial merupakan salah satu upaya untuk memperkecil terjadinya konflik sosial.

Di Indonesia, kelestarian lingkungan telah menjadi kebijakan pemerintah pada setiap periode. Seperti pernyataan Undang-Undang Republik Indonesia No. 32 Tahun 2009 Tentang Perlindungan dan Pengelolaan Lingkungan Hidup pasal 65. Kementrian Lingkungan Hidup membuat suatu program yang dinamakan PROPER (Program Penilaian Peringkat Kinerja Perusahaan dalam Pengelolaan Lingkungan Hidup) dibidang pengendalian dampak lingkungan untuk meningkatkan peran perusahaan dalam program pelestarian lingkungan hidup. Kinerja lingkungan adalah kinerja perusahaan yang peduli dan ikut andil terhadap lingkungan sekitarnya dalam menciptakan lingkungan yang baik (Oktalia, 2014). Pengungkapan PROPER merupakan salah satu pengungkapan non keuangan. Pengungkapan non keuangan ini juga direaksi searah oleh pasar saham (Grewal et al., 2018). Melalui PROPER, kinerja lingkungan suatu perusahaan diperingkat dengan menggunakan lima peringkat warna yang mencakup peringkat emas, hijau, biru, merah, dan hitam yang nantinya diumumkan setiap tahun kepada publik agar masyarakat dapat mengetahui tingkat ketaatan pengelolaan lingkungan pada perusahaan dengan hanya melihat warna yang ada. Peringkat baik diberikan kepada perusahaan yang melakukan pengelolaan lingkungan sesuai dengan regulasi. Peringkat baik ditandai dengan warna emas dan hijau, sementara warna biru merupakan perusahaan yang secara minimum mampu memenuhi regulasi. Peringkat buruk diberikan kepada perusahaan yang melakukan pengelolaan lingkungan belum sesuai dengan regulasi. Peringkat buruk ditandai dengan warna merah dan hitam.

PROPER semakin lama semakin diminati oleh perusahaan, terbukti dengan jumlah peserta PROPER dan tingkat ketaatan terhadap peraturan lingkungan hidup yang semakin meningkat dari tahun ke tahun. Pada tahun 2003 jumlah peserta PROPER sebanyak 85 perusahaan dengan tingkat ketaatan $60 \%$, tahun 2011 jumlah peserta PROPER sebanyak 1.002 perusahaan dengan tingkat ketaatan kurang lebih 72\%, dan tahun 2017 jumlah peserta PROPER sebanyak 1.819 perusahaan dengan tingkat ketaatan kurang lebih 92\% (Kementrian Lingkungan Hidup, 2018).

Perusahaan yang memperoleh peringkat baik terbukti memiliki perhatian sosial yang lebih besar bagi masyarakat dan tenaga kerjanya. Perusahaan dengan peringkat baik tersebut tidak hanya mengungkapkan kinerja lingkungan tetapi juga mengenai kualitas dan keamanan produk, CSR perusahaan terhadap masyarakat, dan kepedulian perusahaan terhadap keselamatan dan 
kesejahteraan tenaga kerjanya (Rakhiemah \& Agustia, 2009). Selain itu pengungkapan melalui media lebih direspon oleh pelaku pasar daripada pengungkapan yang dilakukan oleh perusahaan sendiri (Capelle-Blancard \& Petit, 2019).

Menurut Prabandari \& Suryanawa (2014), saat ini informasi tentang sosial dan lingkungan merupakan salah satu pertimbangan penting bagi pelaku pasar. Gray et al. (1987) menyatakan visi melestarikan lingkungan yang dimiliki oleh manajemen perusahaan telah bertanggung jawab terhadap masyarakat dan lingkungan atas kinerja operasionalnya. Hal ini sesuai dengan penelitian Pflieger et al. (2005) yang menunjukkan bahwa kegiatan pelestarian lingkungan yang dilakukan oleh perusahaan akan menarik investor dan stakeholoders terhadap keuntungan perusahaan yang diakibatkan oleh pengelolaan lingungan yang baik dimata masyarakat. Hasil lain mengatakan bahwa dengan melakukan pengelolaan lingkungan yang baik dapat menghindari klaim masyarakat dan pemerintah serta meningkatkan kualitas produk yang pada akhirnya akan dapat meningkatkan keuntungan finansial perusahaan. Diyakini suatu perusahaan yang kinerja lingkungannya tinggi akan mempengaruhi masyarakat sekitar dan investor sesuai dengan teori legitimasi (Rahmawati, 2011).

Investor seringkali memanfaatkan informasi yang dipublikasikan, karena informasi tersebut memiliki sinyal tentang prospek suatu perusahaan di masa depan. Ketika informasi mengenai perusahaan diungkapkan, investor akan bereaksi negatif atau positif. Reaksi dari investor akan mengakibatkan terjadinya perubahan harga saham. Jika pasar bereaksi terhadap sebuah informasi selama periode pengamatan, maka informasi tersebut menjadi penyebab terjadinya abnormal return yang selanjutnya menjadi proksi reaksi pasar. Return tak normal (abnormal return) merupakan selisih antara return realisasian dengan return ekspektasian. Return realisasian merupakan return yang sudah terjadi sedangkan return ekspektasian merupakan return yang diharapkan dan belum terjadi (Brown \& Warner, 1980). Selisih return akan positif jika return yang didapatkan lebih besar dari return yang diharapkan, sedangkan return akan negatif jika return yang didapatkan lebih kecil dari return yang diharapkan.

Beberapa hasil penelitian menunjukkan hasil yang berbeda terhadap tema lingkungan. Penelitian Kusumo \& Nugrahanti (2017) menyimpulkan bahwa terdapat perbedaan abnormal return yang positif pada sebelum dan sesudah pengumuman PROPER. Murguia et al., (2012) menemukan bahwa pengumuman peringkat kinerja lingkungan di US mampu membuat pasar bereaksi positif yang ditunjukkan melalui perubahan harga saham. Penelitian Cheng (2011) mendapatkan hasil bahwa pengungkapan Corporate Social Responsibility memiliki pengaruh positif terhadap abnormal return. Penelitian Flammer (2013) menemukan bahwa perusahaan yang melaporkan kinerja lingkungan secara bertanggung jawab mengalami kenaikan harga saham. Reddy \& Gordon (2010) menemukan bahwa CSR berpengaruh positif terhadap abnormal return bagi perusahaan-perusahaan di New Zealand. Penelitian Desfita (2009) menyimpulkan bahwa pengumuman PROPER berpengaruh positif terhadap harga saham industri manufaktur. Dasgupta et al. (2001) mendapatkan hasil bahwa pasar bereaksi positif terhadap perusahaan dengan kinerja lingkungan 
yang baik dan bereaksi negatif terhadap perusahaan dengan kinerja lingkungan yang buruk.

Penelitian mengenai kinerja lingkungan yang mendapatkan hasil negatif ditunjukkan oleh penelitian Utami (2016) menemukan bahwa tidak ada reaksi pasar pada tanggal pengumuman PROPER. Penelitian Wiranata \& Wirajaya (2014) menemukan bahwa nilai rata-rata abnormal return pada saat pengumuman dan dua hari setelah pengumuman peringkat kinerja perusaahaan dalam pengelolaan lingkungan memberikan reaksi yang negatif signifikan. Prasetio (2010) menyimpulkan bahwa pengungkapan kinerja lingkungan yang diproksikan dalam pemeringkatan PROPER berpengaruh negatif terhadap reaksi pasar. Suranta (2010) menyimpulkan bahwa pengungkapan Corporate Social Responsibility berpengaruh negatif terhadap abnormal return. Penelitian Prasetyo (2007) menemukan bahwa kualitas kinerja lingkungan perusahaan tidak menyebabkan munculnya reaksi yang dapat menyebabkan munculnya abnormal return. Oberndorfer (2006) mendapatkan hasil bahwa ada dampak negatif dari regulasi tersebut terhadap pasar saham di Jerman.

Berdasarkan uraian yang telah dipaparkan diatas, maka permasalahan yang dapat diangkat dalam penelitian ini adalah: (1) Apakah pengumuman PROPER direaksi oleh pasar modal? (2) Apakah terdapat perbedaan reaksi pasar antara peringkat baik dan peringkat buruk?

Teori sinyal membahas bagaimana sebuah informasi yang dipublikasikan dapat memberikan sinyal bagi investor dalam pengambilan keputusan investasi. Pada saat informasi diungkapkan dan pelaku pasar telah menerima informasi tersebut, pelaku pasar terlebih dahulu menginterpretasikan dan menganalisis informasi tersebut sebagai sinyal baik (good news) atau sinyal buruk (bad news). Informasi yang berkaitan dengan perusahaan akan memberikan umpan balik dari investor atas informasi tersebut (Watts, 2000). Jika pengumuman informasi tersebut sebagai good news bagi pelaku pasar, maka terjadi perubahan dalam harga saham yang semakin naik dan begitu pula sebaliknya. Teori legitimasi menjelaskan bahwa perusahaan harus mampu meyakinkan masyarakat bahwa kegiatan-kegiatan yang dilakukan oleh perusahaan telah sesuai dengan regulasi dan norma yang dipercayai oleh masyarakat (Naser et al., 2006).

Menurut Hartono (2017:643) studi peristiwa merupakan studi yang mempelajari reaksi pasar terhadap suatu peristiwa yang informasinya dipublikasikan sebagai suatu pengumuman. Abnormal return merupakan indikator untuk mengukur adanya reaksi pasar. Apabila terdapat abnormal return pada saat pengumuman PROPER menandakan bahwa pasar bereaksi terhadap informasi tersebut.

Adapun penelitian Kusumo \& Nugrahanti (2017) menyimpulkan bahwa terdapat perbedaan abnormal return yang positif pada sebelum dan sesudah pengumuman PROPER. Penelitian Flammer (2013) menemukan bahwa perusahaan yang melaporkan kinerja lingkungan secara bertanggung jawab mengalami kenaikan harga saham. Penelitian Desfita (2009) menyimpulkan bahwa pengumuman PROPER berpengaruh positif terhadap harga saham industri manufaktur. Berdasarkan hasil penelitian dari beberapa peneliti yang menyatakan pasar bereaksi positif terhadap pengumuman PROPER. Maka hipotesis penelitian dapat dinyatakan sebagai berikut: 
$\mathrm{H}_{1}$ : Pengumuman PROPER direaksi positif oleh pasar modal.

PROPER sebagai program penilaian peringkat kinerja lingkungan terbagi menjadi lima kategori peringkat dengan penggunaan warna emas, hijau, biru, merah, dan hitam sebagai bentuk komunikatif penyampaian kinerja lingkungan suatu perusahaan kepada masyarakat yang kemudian menjadi sebuah sinyal bagi para pelaku pasar untuk membuat suatu keputusan investasi. Peringkat baik diberikan kepada perusahaan melakukan pengelolaan lingkungan sesuai dengan regulasi. Peringkat baik ditandai dengan warna emas dan hijau. Peringkat buruk diberikan melakukan pengelolaan lingkungan belum sesuai dengan regulasi. Peringkat buruk ditandai dengan warna merah dan hitam.

Pengumuman PROPER merupakan sebuah informasi karena mencerminkan kinerja lingkungan perusahaan dan gambaran mengenai prospek perusahaan dimasa mendatang. Perusahaan yang mendapatkan peringkat baik dianggap memiliki prospek yang baik pula dan diharapkan agar terbebas dari kasus pencemaran lingkungan dimasa mendatang. Oleh karena itu, perusahaan dianggap mampu dan akan meningkatkan citra baik perusahaan sehingga akan mendapatkan legitimasi dari masyarakat, sedangkan perusahaan dengan peringkat buruk dianggap belum bisa mengendalikan pencemaran lingkungan dan bisa saja timbul kasus hukum atas pencemaran yang dapat memberikan citra buruk terhadap perusahaan.

Menurut Endrikat (2016), pasar merespon berbeda antara perusahan peringkat bawah dengan atas. Perusahaan yang memperoleh peringkat baik akan direspon positif oleh investor yang ditunjukan melalui naiknya harga saham dari perioda ke perioda. Sebaliknya, perusahaan dengan peringkat buruk maka akan muncul keraguan dari investor terhadap perusahaan tersebut dan direspon negatif dengan fluktuasi harga saham perusahaan dipasar yang semakin menurun dari tahun ke tahun (Haholongan, 2016). Berdasarkan pemaparan diatas, maka hipotesis penelitian dapat dinyatakan sebagai berikut:

$\mathrm{H}_{2}$ : Terdapat reaksi pasar yang berbeda antara peringkat baik dan peringkat buruk.

\section{METODE PENELITIAN}

Metode penelitian yang digunakan dalam penelitian ini adalah studi peristiwa (event study). Studi peristiwa merupakan studi yang mempelajari reaksi pasar tehadap suatu peristiwa yang informasinya dipublikasikan sebagai suatu pengumuman (Hartono, 2017:643). Peristiwa yang diuji dalam penelitian ini adalah pada saat pengumuman peringkat kinerja perusahaan dalam pengelolaan lingkungan hidup dengan menggunakan jendela peristiwa (event window) selama 5 hari. Penggunaan event window selama 5 hari bertujuan untuk memperkecil adanya informasi lain yang mempengaruhi terjadinya perubahan harga saham perusahaan yang bersangkutan, apabila digunakan event window yang terlalu lama, dikhawatirkan terdapat peristiwa lain yang dapat mempengaruhi hasilnya (Hartono, 2017).

Penelitian ini meggunakan data sekunder dimana data yang diperoleh diakses melalui website www.proper.menlh.go.id, www.idx.co.id dan www.finance.yahoo.com. Berdasarkan hipotesis yang diajukan, variabel yang digunakan adalah variabel dependen reaksi pasar modal yang diuji dengan 
average abnormal return. Variabel independen yakni pengumuman peringkat kinerja perusahaan dalam pengelolaan lingkungan hidup.

Populasi dalam penelitian ini adalah perusahaan yang mengikuti PROPER yang terdaftar di Bursa Efek Indonesia pada tahun 2015, 2016, dan 2017. Sementara sampel dalam penelitian ini adalah perusahaan-perusahaan yang pada saat event window pengumuman PROPER tidak melakukan corporate action (stock split, right issue, pengumuman dividen, saham bonus, warrant, dan RUPS) dengan maksud untuk menghindari confounding effect atau tercampurnya informasi dari suatu peristiwa dengan peristiwa lain. Total sampel dalam penelitian ini adalah 39 sampel dengan kriteria dan penyeleksian terlihat pada Tabel 1.

\section{Tabel 1. Hasil Seleksi Pemilihan Sampel}

\begin{tabular}{lll}
\hline No. & Kriteria & Jumlah Perusahaan \\
\hline 1 & Perusahaan yang mengikuti PROPER yang terdaftar di & 111 \\
& Bursa Efek Indonesia tahun 2015-2017. & \\
2 & Perusahaan yang termasuk peringkat biru & $(53)$ \\
3 & Perusahaan yang pada saat event window pengumuman & \\
& PROPER melakukan corporate action: & \\
& Right issue & $(3)$ \\
& Dividen & $(3)$ \\
& Stock Split & $(3)$ \\
& Jumlah sampel penelitian & 49 \\
& Data outlier & $(10)$ \\
& Total data observasi & 39 \\
\hline
\end{tabular}
Sumber: Data Penelitian, 2019

Uji yang pertama dilakukan yakni uji normalitas. Uji normalitas bertujuan untuk menguji apakah data yang dipergunakan dalam penelitian ini berdistribusi normal atau tidak. Untuk menguji normalitas suatu data dapat dilakukan dengan uji Kolmogorov-Smirnov.

Uji-t signifikansi dalam penelitian ini diuji menggunakan uji one sample $t$ test selama 5 hari periode peristiwa. Tujuan pengujian dengan one sample t-test adalah untuk memperlihatkan apakah pada peristiwa terdapat abnormal return yang signifikan disekitar pengumuman PROPER. Pengujian analisis dalam penelitian ini menggunakan Program SPSS. Pengambilan keputusan menggunakan tingkat kepercayaan 95\% atau $\alpha=0,05$ dengan kriteria (Ghozali, 2016:66). Jika nilai probabilitas $>0,05$, maka $\mathrm{H}_{1}$ ditolak dan jika nilai probabilitas $\leq 0,05$, maka $\mathrm{H}_{1}$ diterima.

Menurut Ghozali (2016) uji beda t-test digunakan untuk menguji seberapa jauh pengaruh variabel independen yang digunakan dapat menerangkan variabel dependen secara parsial.

\section{HASIL DAN PEMBAHASAN}

Uji pertama yang dilakukan yakni uji normalitas. Berdasarkan Tabel 2 dapat diketahui nilai signifikansi dari abnormal return peringkat baik 2 hari sebelum peristiwa sebesar 0,259>0,05, 1 hari sebelum peristiwa sebesar 0,101 >0,05, pada hari peristiwa sebesar 0,184 $>0,05,1$ hari setelah peristiwa sebesar 0,920 >0,05, dan 2 hari setelah peristiwa sebesar 0,683 >0,05 yang berarti data berdistribusi 
normal, sehingga dapat diteruskan analisisnya ke dalam uji one sample t-test dan uji independent $t$-test.

Berdasarkan Tabel 2 dapat diketahui nilai signifikansi dari abnormal return peringkat buruk 2 hari sebelum peristiwa sebesar 0,509>0,05, 1 hari sebelum peristiwa sebesar 0,829 >0,05, pada hari peristiwa sebesar 0,965 >0,05, 1 hari setelah peristiwa sebesar 0,448 >0,05, dan 2 hari setelah peristiwa sebesar 0,792 > 0,05 yang berarti data berdistribusi normal, sehingga dapat diteruskan analisisnya ke dalam uji one sample t-test dan uji independent $t$-test.

Tabel 2. Hasil Uji Normalitas Peringkat Baik dan Peringkat Buruk

\begin{tabular}{lllll}
\hline \multirow{2}{*}{ Periode Peristiwa } & \multicolumn{3}{c}{ Peringkat Baik } & Peringkat Buruk \\
\cline { 2 - 5 } & $\mathrm{N}$ & Sig. & 11 & Sig. \\
\hline $\mathrm{t}-2$ & 28 & 0,259 & 11 & 0,509 \\
$\mathrm{t}-1$ & 28 & 0,101 & 11 & 0,829 \\
$\mathrm{t} 0$ & 28 & 0,184 & 11 & 0,965 \\
$\mathrm{t}+1$ & 28 & 0,920 & 11 & 0,448 \\
$\mathrm{t}+2$ & 28 & 0,683 & & 0,792 \\
\hline
\end{tabular}

Sumber: Data Penelitian, 2019

Berdasarkan tabel dan grafik di atas, secara keseluruhan nilai return realisasi masih berada dalam angka negative. Berikut adalah nilai return realisasi yang dapat dilihat pada tabel 3.

Tabel 3. Return Realisasi Perusahaan Peserta PROPER Peringkat Baik dan Peringkat Buruk

\begin{tabular}{lll}
\hline Hari ke & Rata-Rata Peringkat Baik & Rata-Rata Peringkat Buruk \\
\hline-2 & 0,013 & 0,007 \\
-1 & 0,004 & 0,001 \\
0 & $-0,007$ & $-0,005$ \\
1 & $-0,001$ & $-0,001$ \\
2 & $-0,005$ & $-0,002$ \\
\hline
\end{tabular}

Sumber: Data Penelitian, 2019

Gambar 1 merupakan nilai rata-rata return realisasi untuk peringkat baik dan peringkat buruk.

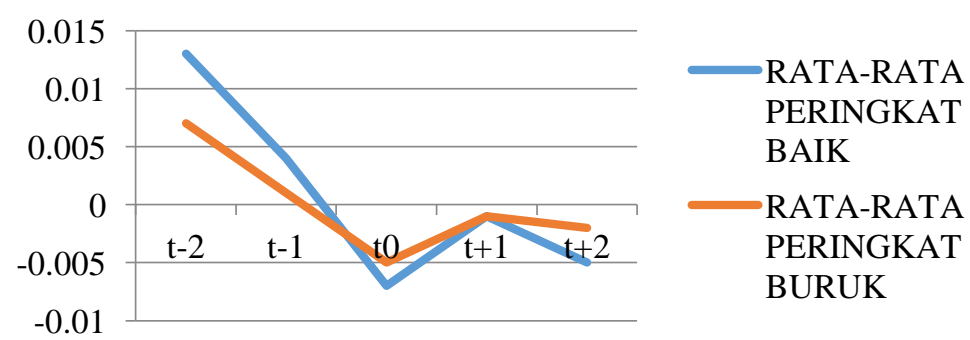

\section{Gambar 1. Grafik Return Realisasi Perusahaan Peserta PROPER Peringkat Baik dan Peringkat Buruk}

Sumber: Data Penelitian, 2019

Perhitungan nilai return ekspektasi dalam penelitian ini menggunakan market adjusted model. Nilai return ekspektasian disajikan dalam tabel 4. 
Tabel 4. Return Ekspektasi Perusahaan Peserta PROPER Peringkat Baik dan Peringkat Buruk

\begin{tabular}{llllll}
\hline Tahun & $\mathrm{t}-2$ & $\mathrm{t}-1$ & $\mathrm{t} 0$ & $\mathrm{t}+1$ & $\mathrm{t}+2$ \\
\hline 2015 & 0,005 & 0,009 & $-0,004$ & 0,001 & 0,009 \\
2016 & 0,005 & $-0,001$ & 0,007 & 0,001 & $-0,003$ \\
2017 & 0,010 & 0,001 & 0,002 & 0,005 & $-0,009$ \\
\hline
\end{tabular}

Sumber: Data Penelitian, 2019

Nilai abnormal return yaitu selisih antara return realisasi dengan return ekspektasi. Pada tabel 5 dapat dilihat nilai rata-rata abnormal return untuk peringkat baik dan buruk mengalami fluktuasi dan lebih cenderung berada dalam angka negatif.

Rata-rata nilai abnormal return dapat disajikan dalam tabel 5.

Tabel 5. Abnormal Return Perusahaan Peserta PROPER Peringkat Baik dan Peringkat Buruk

\begin{tabular}{lll}
\hline Hari ke & Rata-Rata Peringkat Baik & Rata-Rata Peringkat Buruk \\
\hline-2 & 0,006 & 0,000 \\
-1 & 0,001 & $-0,003$ \\
0 & $-0,010$ & $-0,006$ \\
1 & $-0,004$ & $-0,004$ \\
2 & $-0,003$ & $-0,001$ \\
\hline
\end{tabular}

Sumber: Data Penelitian, 2019

Pada tabel 5 dapat dilihat nilai rata-rata abnormal return untuk peringkat baik dan buruk mengalami fluktuasi dan lebih cenderung berada dalam angka negatif.

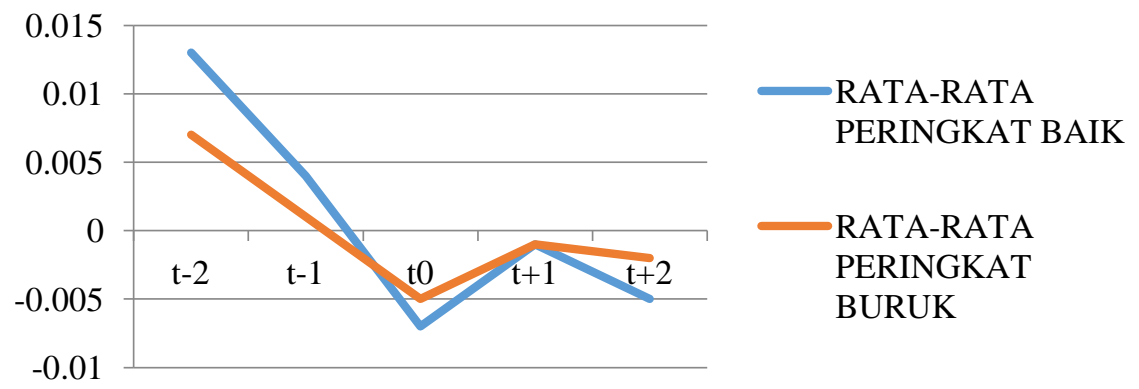

\section{Gambar 2. Grafik Abnormal Return Perusahaan Peserta PROPER Peringkat Baik dan Peringkat Buruk}

Sumber: Data Penelitian, 2019

Hasil uji one sample t-test dilakukan untuk menguji hipotesis 1 yaitu pengumuman PROPER direaksi positif oleh pasar modal di Indonesia. Variabel yang digunakan adalah abnormal return peringkat baik dan peringkat buruk. Hasil pengujian disajikan pada tabel 6 dibawah ini.

Tabel 6. Uji One Sample T-Test Peringkat Baik

\begin{tabular}{|c|c|c|c|c|c|c|}
\hline & Test V & $\mathrm{e}=$ & & & & \\
\hline & $\mathrm{t}$ & $\mathrm{df}$ & Sig. (2-tailed) & $\begin{array}{l}\text { Mean } \\
\text { Difference }\end{array}$ & $\begin{array}{l}95 \% \mathrm{C} \\
\text { of the I }\end{array}$ & $\begin{array}{l}\text { nce Interval } \\
\text { nce }\end{array}$ \\
\hline & & & & & Lower & Upper \\
\hline $\mathrm{t}-2$ & 1,545 & 27 & 0,134 & 0,006 & $-0,002$ & 0,014 \\
\hline
\end{tabular}

Bersambung ... 
Lanjutan Tabel 6.

\begin{tabular}{lllllll}
\hline $\mathrm{t}-1$ & 0,324 & 27 & 0,749 & 0,001 & $-0,008$ & 0,011 \\
$\mathrm{t} 0$ & $-2,206$ & 27 & 0,036 & $-0,009$ & $-0,018$ & $-0,001$ \\
$\mathrm{t}+1$ & $-0,937$ & 27 & 0,357 & $-0,003$ & $-0,011$ & 0,004 \\
$\mathrm{t}+2$ & $-1,281$ & 27 & 0,211 & $-0,003$ & $-0,008$ & 0,002 \\
\hline
\end{tabular}

Sumber: Data Penelitian, 2019

Berdasarkan tabel 6 diatas menunjukan bahwa pada saat pengumuman PROPER secara statistik dinyatakan signifikan sebesar 0,036 $<0,05$ dan memperoleh nilai t sebesar -2,206 yang menunjukan bahwaterdapat reaksi pasar yang negatif atas pengumuman PROPER dengan peringkat baik.

Berdasarkan tabel 7 diatas menunjukan bahwa pada saat pengumuman PROPER secara statistik dinyatakan signifikan sebesar $0,035<0,05$ dan memperoleh nilai $\mathrm{t}$ sebesar $-2,435$ yang menunjukan bahwaterdapat reaksi pasar yang negatif atas pengumuman PROPER dengan peringkat buruk.

Tabel 7.Uji One Sample T-Test Peringkat Buruk

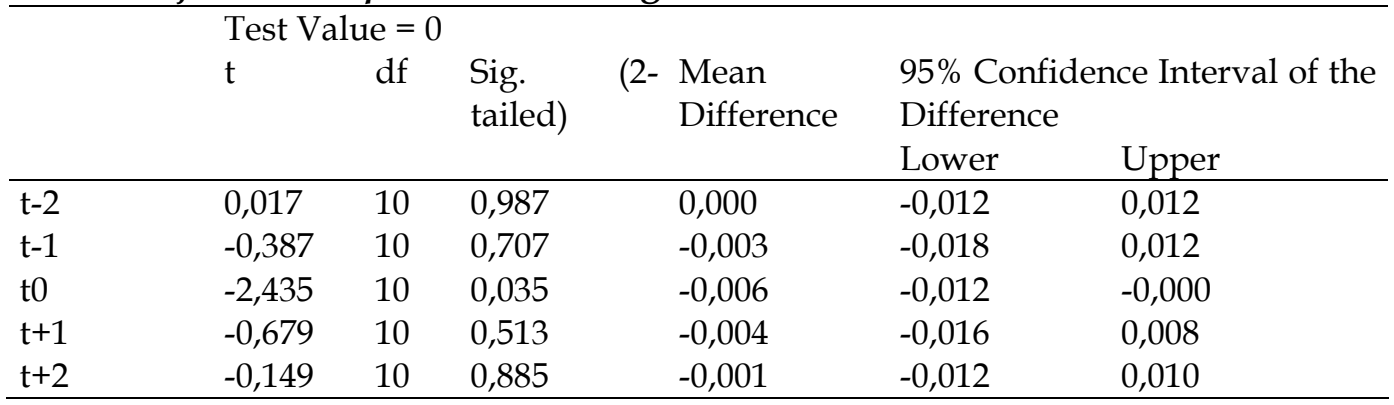

Sumber: Data Penelitian, 2019

Berdasarkan hasil tersebut diatas, peringkat baik dan peringkat buruk direaksi negatif oleh pasar modal yang ditunjukan dengan nilai probabilitas sebesar 0,036 < 0,05 dan 0,035 <0,05, yang berarti $\mathrm{H}_{1}$ ditolak.

Berdasarkan hasil uji independent $t$-test dilakukan untuk menguji hipotesis 2 yaitu terdapat reaksi pasar yang berbeda antara peringkat baik dan peringkat buruk. Variabel yang digunakan adalah abnormal return pada saat pengumuman PROPER. Hasil pengujian disajikan pada Tabel 8 dibawah ini.

\section{Tabel 8.Uji Independent T-Test}

\begin{tabular}{lllll}
\hline Keterangan & Peringkat Baik & Peringkat Buruk & Sig. (2-tailed) & t \\
\hline $\begin{array}{l}\text { Rata-rata } \\
\text { abnormal return }\end{array}$ & $-0,009$ & $-0,006$ & 0,652 & $-0,454$
\end{tabular}

Sumber: Data Penelitian, 2019

Berdasarkan tabel diatas, abnormal returnperingkat baik memperoleh nilai rata-rata sebesar $-0,009$ dan abnormal return peringkat buruk memperoleh nilai rata-rata sebesar $-0,006$. Nilai t sebesar $-0,454$ dan nilai signifikansi sebesar 0,652 $>0,05$ yang menunjukkan bahwa tidak terdapat reaksi pasar yang berbeda antara peringkat baik dan peringkat buruk, atau $\mathrm{H}_{2}$ ditolak.

Hasil penelitian ini menunjukkan bahwa pada hari pengumuman peringkat kinerja perusahaan dalam pengelolaan lingkungan hidup memiliki kandungan informasi yang dapat mempengaruhi investor dalam membuat keputusan berinvestasinya. Namun, informasi tersebut dianggap sebagai bad news sehingga direaksi negatif oleh investor. 
Perusahaan yang memperoleh peringkat buruk tidak melaksanakan persyaratan PROPER sebagaimana mestinya, sehingga dapat menimbulkan kasus pencemaran lingkungan yang dapat merusak citra perusahaan. Perusahaan yang terbukti mencemari lingkungan, dapat dikenakan tindak pidana hingga digugat untuk mengganti kerugian atas pencemaran lingkungan tersebut. Oleh karena itu, peringkat buruk PROPER sudah semestinya direaksi negatif oleh pasar modal.

Hasil penelitian ini sejalan dengan penelitian sebelumnya yaitu: Wiranata \& Wirajaya (2014) menemukan bahwa nilai rata-rata abnormal return pada saat pengumuman dan dua hari setelah pengumuman peringkat kinerja perusaahaan dalam pengelolaan lingkungan memberikan reaksi yang negatif signifikan. Prasetio (2010) menyimpulkan bahwa pengungkapan kinerja lingkungan yang diproksikan dalam pemeringkatan PROPER berpengaruh negatif terhadap reaksi pasar.

Hasil penelitian ini menunjukkan bahwa pada hari pengumuman peringkat kinerja perusahaan dalam pengelolaan lingkungan hidup baik dari peringkat baik dan peringkat buruk sama-sama direaksi negatif oleh pasar modal. PROPER merupakan sebuah program milik pemerintah yang mana program tersebut dapat dipercaya informasinya karena dalam pelaksanaan penilaian kinerja lingkungan perusahaan terdapat tahap-tahap yang harus dilalui oleh peserta proper agar dapat menunjukan kualitas kinerja lingkungan perusahaannya. Investor seharusnya merespon positif informasi yang tergolong good news dan merespon negatif informasi yang tergolong bad news. Namun, hasil uji dalam penelitian ini menunjukan investor juga merespon negatif peringkat baik yang merupakan informasi good news. Hal tersebut mungkin dikarenakan investor belum mengapresiasi pengelolaan lingkungan hidup, dimana pasar modal cenderung lebih cepat merespon bad news daripada good news.

Selain faktor-faktor tersebut diatas, hal lain yang mungkin menyebabkan investor sama-sama bereaksi negatif terhadap peringkat baik dan peringkat buruk yaitu kurangnya pemahaman investor mengenai makna dari peringkat PROPER dan kurang mempertimbangkan dampak dan prospek yang dapat terjadi dimasa mendatang oleh pemeringkatan PROPER. Hasil penelitian ini sejalan dengan penelitian sebelumnya yaitu : Wiranata \& Wirajaya (2014) menemukan bahwa tidak terdapat perbedaan reaksi pasar antara peringkat emas dan peringkat merah. Kusumo \& Nugrahanti (2017) menemukan bahwa tidak terdapat perbedaan abnormal return antar peringkat PROPER. Prasti (2018) menemukan bahwa tidak terdapat perbedaan reaksi yang dihasilkan atas pengumuman peringkat emas, hijau, biru, emas, dan hitam.

\section{SIMPULAN}

Berdasarkan hasil analisis dan pembahasan yang telah dilakukan sebelumnya, dapat disimpulkan bahwa pengumuman PROPER direaksi negatif oleh pasar modal dan tidak terdapat perbedaan reaksi pasar antara peringkat baik dan peringkat buruk pada pengumuman PROPER.

Berdasarkan hasil penelitian dan simpulan, maka saran yang dapat diberikan bagi peneliti selanjutnya diharapkan lebih menyempurnakan penelitian ini dengan menggunakan model perhitungan abnormal return yang 
lainnya seperti mean adjusted model, serta memperpanjang periode pengamatan untuk mendapatkan data yang lebih banyak agar hasil yang diperoleh lebih representatif. Peneliti selanjutnya juga sebaiknya mengkategorikan penelitian dengan berdasarkan tipe industri atau ukuran perusahaan agar sampel penelitiannya terfokus ke golongan tertentu.

\section{REFERENSI}

Alhaddi, H. (2015) 'Triple Bottom Line and Sustainability: A Literature Review', Business and Management Studies, 1(2), pp. 6-10. Available at: https://doi.org/10.11114/bms.v1i2.752.

Brown, S. \& Warner, J. (1980) 'Measuring Security Price Performance', 8, pp. 205208.

Capelle-Blancard, G., \& Petit, A. (2019) ‘Every Little Helps? ESG News and Stock Market Reaction', Journal of Business Ethics, 157(2), pp. 543-565. Available at: https:/ / doi.org/10.1007/s10551-017-3667-3.

Cheng, M. and Christiawan, Y. J. (2011) 'Pengaruh Pengungkapan Corporate Social Responsibility Terhadap Abnormal Return', Jurnal Akuntansi dan Keuangan, 13(1), pp. 24-36. doi: 10.9744/jak.13.1.24-36.

Dasgupta, S., Laplante, B. and Mamingi, N. (2001) 'Pollution and capital markets in developing countries', Journal of Environmental Economics and Management, 42(3), pp. 310-335. doi: 10.1006/jeem.2000.1161.

Desfita, M. (2009) Pengaruh Pengumuman Peringkat Kinerja Lingkungan Terhadap Perubahan Harga Saham Perusahaan (Studi pada Perusahaan Manufaktur di Busa Efek Indonesia). Universitas Andalas.

Endrikat, J. (2016) 'Market Reactions to Corporate Environmental Performance Related Events: A Meta-analytic Consolidation of the Empirical Evidence', Journal of Business Ethics, 138(3), pp. 535-548. doi: 10.1007/s10551-015-25980.

Flammer, C. (2013) 'Corporate Social Responsibility And Shareholder Reaction: The Environmental Awareness Of Investors', 56(3), pp. 758-781.

Ghozali, I. (2016) Aplikasi Analisis Multivariate dengan Program SPSS. Yogyakarta: Badan Penerbit BPFE.

Gray, R., Owen, D. and Maunders, K. (1987) Corporate Social Reporting: Accounting and Accountability. London: Prentice-Hall.

Grewal, J., Riedl, E. J. and Serafeim, G. (2018) 'Market Reaction to Mandatory Nonfinancial Disclosure', Management Science, (August), pp. 1-24. doi: 10.1287/mnsc.2018.3099.

Haholongan, R. (2016) 'Kinerja Lingkungan dan Kinerja Ekonomi Perusahaan Manufaktur Go Public', 19(3), pp. 413-423.

Hartono, J. (2017) Teori Portofolio dan Analisis Investasi. Yogyakarta: BPFE.

Hidup, K. L. (2018). Proper. Retrieved January 1, 2019, from https:// proper.menlhk.go.id/portal/

Indonesia, V. (2018) 'Kasus Lapindo: 12 Tahun Semburan Lumpur Ancam Kesehatan Warga', VOA Indonesia, October.

Kusumo, V.W., \& Nugrahanti, Y. W. (2017) ‘Reaksi Pasar di Seputar Pengumuman Proper', XXII(3), pp. 421-439.

Murguia, J. M. \& Lence, S. H. (2012) 'Investors' Reaction to Environmental 
Performance: a Global Perspektive of the Newsweek's Green Rankings'. Available at: http://scholar.qsensei.com/content/ltng78.

Naser, K., Al-Hussaini, A., Al-Kwari, D., \& Nuseibeh, R. (2006) ‘Determinans of Corporate Social Disclosure in Developing Countries: The Case of Qatar', 19, pp. 1-23.

Nasution, A. Z. (2018). Kerusakan Lingkungan Freeport atau Environmental Damage Freeport. Retrieved January 1, 2019, from https://bangazul.com/\#

Oktalia, D. (2014) Pengaruh Kinerja Lingkungan dan Profitabilitas Terhadap Corporate Sosial Responsibility Disclosure Dalam Laporan Tahunan Perusahaan (Studi Empiris pada Perusahaan Go Public yang Terdaftar di BEI 2009-2012). Universitas Negeri Padang.

Oberndorfer, U. \& Ziegler, A. (2006) 'Environmentally Oriented Energi Policy and Stock Return, Center of European Economic Research'.

Pflieger, J., Fischer, M., Kupfer, Thilo., \& Eyerer, P. (2005) 'The Contribution of Life Cycle Assessment to Global Sustainability Reporting of Organization', 1.

Prabandari, K. R. and Suryanawa, K. (2014) ‘Pengaruh Environmental Performance Pada Reaksi Investor Di Perusahaan High Profile Bursa Efek Indonesia', E-Jurnal Akuntansi, 7(2), pp. 299-312.

Prasetio, B. T. (2010) 'Pengaruh Mekanisme Corporate Governance, Kinerja Lingkungan dan Pengungkapan Lingkungan Perusahaan Terhadap Reaksi Pasar', El-muhasaba, 4(1), pp. 1-25.

Prasetyo, W. (2007) Analisis Perbedaan Return, Abnormal Return dan Trading Volume Activity Saham Perusahaan Pertambangan Minyak dan gas di BEJ Sebelum dan Sesudah Bencana Lumpur Panas PT. Lapindo Brantas diSidoarjo. Universitas Negeri Malang.

Prasti, T. V. (2018) Analisis Reaksi Pasar atas Pengumuman Peringkat Perusahaan pada Program Penilaian Peringkat Kinerja Perusahaan Dalam Pengelolaan Lingkungan Hidup (PROPER). Universitas Airlangga.

Rahmawati, A. (2011) Pengaruh Kinerja Lingkungan terhadap Kinerja Finansial Perusahaan dengan Corporate Social Responsibility (CSR) Disclousure sebagai Variabel Intervening. Universitas Diponegoro.

Rakhiemah, A. N. and Agusta, D. (2009) 'Pengaruh kinerja lingkungan terhadap Keuangan Pemrintah', in Pengaruh kinerja lingkungan terhadap Keuangan Pemrintah. Palembang: Simposium Nasional Akuntansi XII, pp. 1-31.

Reddy, K. and Gordon, L. W. (2010) 'The effect of sustainability reporting on financial performance: An empirical study using listed companies', Journal of Asia Entrepreneurship and Sustainability, 6(2), pp. 19-42.

Shrivastava, P. (1995) 'The Role of Corpoorations in Achieving Ecogological Sustainability', 20, pp. 936-960.

Sri Tjahjono, M. (2013) 'Pengaruh Kinerja Lingkungan Terhadap Nilai Perusahaan dan Kinerja Keuangan', Jurnal Ekonomi, 4(1).

Suranta, E. (2010) Analisis CSR Disclosure Terhadap Reaksi Investor (Studi Empiris pada Perusahaan yang Terdaftar di BEI). Universitas Bengkulu.

Undang-Undang Republik Indonesia No. 32 Tahun 2009 Tentang Perlindungan dan Pengelolaan Lingkungan Hidup (2009). Indonesia: Kementrian Lingkungan 
Hidup.

Utami, D. N. (2016) Reaksi Pasar Terhadap Pengumuman Peringkat Kinerja Lingkungan dan Penghargaan Laporan Tanggung Jawab Sosial (Studi Peristiwa pada Perusahaan Pertambangan Terdaftar di BEI Tahun 2013-2015). Universitas Gajah Mada.

Watts, R. L. (2000) 'Conservatism in Accounting Part I: Explanations and Implication', Accounting Horizons, 17(3), pp. 207-221.

Wiranata, I. W. E. and Wirajaya, I. G. A. (2014) 'Reaksi Pasar Atas Pengumuman Peringkat Kinerja Perusahaan Dalam Pengelolaan Lingkungan', E-Jurnal Akuntansi, 8(3), pp. 408-422. 